\section{Diesel Exhaust Particulates}

CAS No.: none assigned

Reasonably anticipated to be a human carcinogen

First listed in the Ninth Report on Carcinogens (2000)

\section{Carcinogenicity}

Exposure to diesel exhaust particulates is reasonably anticipated to be a human carcinogen, based on limited evidence of carcinogenicity from studies in humans and supporting evidence from studies in experimental animals and mechanistic studies.

\section{Cancer Studies in Humans}

There is limited evidence for the carcinogenicity of diesel exhaust from studies in humans. Occupational exposure to diesel exhaust particulates was associated with elevated lung-cancer rates in the majority of studies, principally in transportation or construction workers exposed to diesel exhaust (IARC 1989, Cohen and Higgins 1995, Bhatia et al. 1998). Meta-analyses by Cohen and Higgins (1995) and Bhatia et al. (1998) suggested an overall relative risk of approximately 1.3 to 1.5 for lung cancer; some studies found higher risks in more heavily exposed subgroups. The increased risk was not readily explained by confounding from smoking or exposure to asbestos. However, only some studies used quantitative or semi-quantitative assessments of exposure, and many studies used inadequate measures of exposure.

Since diesel exhaust particulates were listed in the Ninth Report on Carcinogens, additional epidemiological studies have been identified. A meta-analysis reported that exposure to diesel exhaust increased the relative risk for lung cancer (Lipsett and Campleman 1999), and additional cohort and case-control studies reported relative risks in the range of 1.2 to 2.21 (Bruske-Hohlfeld et al. 2000, Gustavsson et al. 2000, Larkin et al. 2000, Järvholm and Silverman 2003, Kauppinen et al. 2003, Garshick et al. 2004, 2006, 2008, Laden et al. 2006, Parent et al. 2007, Neumeyer-Gromen et al. 2009). In the majority of studies in which adjustments were made for smoking or other exposures, the increase in risk was not substantially altered; however, as in earlier studies, residual confounding or interactions could not be ruled out. Some studies found higher risk estimates among individuals with higher cumulative exposure (Neumeyer-Gromen et al. 2009) or duration of exposure (Laden et al. 2006, Garshick et al. 2008). Some studies have also reported increased risks of cancer at other tissue sites, particularly the urinary bladder, but the evidence is generally less consistent than that for lung cancer (Boffetta and Silverman 2001, Boffetta 2004).

\section{Cancer Studies in Experimental Animals}

Exposure to diesel exhaust caused tumors in two rodent species, at two different tissue sites, and by several different routes of administration. In numerous studies, inhalation of whole diesel exhaust caused benign or malignant lung tumors (mainly adenoma, squamous-cell carcinoma, or adenocarcinoma) in rats of both sexes (IARC 1989, Brightwell et al. 1989, Nikula et al. 1995, Heinrich et al. 1995). Carcinogenicity appeared to be due to the particulate component of the exhaust, because the filtered vapor phase of exhaust did not cause lung tumors (Brightwell et al. 1989, Heinrich et al. 1995). Dermal exposure to solvent extracts of diesel exhaust particles caused benign and malignant skin tumors in mice of both sexes, and implantation of wax pellets containing the extracts into the lungs of female rats caused benign and malignant lung tumors (bronchiolar/alveolar adenoma and carcinoma and squamous-cell carcinoma) (IARC 1989).

\section{Studies on Mechanisms of Carcinogenesis}

Diesel exhaust contains known mutagens and carcinogens both in the vapor phase and associated with respirable particles (NTP 2000). Diesel exhaust particles are considered likely to account for the human lung cancer findings, because (1) they are almost all small enough to penetrate to the alveolar region in human lungs and (2) mutagenic and carcinogenic chemicals, including polyaromatic hydrocarbons (PAHs) and nitroarenes, have been extracted from these particles with organic solvents or with a lipid component of mammalian lung surfactant. In addition, only diesel exhaust that was not filtered to remove particles caused lung tumors in rats (Brightwell et al. 1989, Heinrich et al. 1995).

Although exposure to diesel exhaust particulates caused lung cancer in rats, the relevance of this finding for predicting carcinogenicity in humans has been questioned (NTP 2000). Exposure to diesel exhaust particulates caused a spectrum of inflammatory and neoplastic pulmonary responses in rats that are characteristic of responses also seen with other inhaled particles of varying toxicity. These responses apparently are little influenced by the chemical constituents of the particles. The precise bioavailability of chemical mutagens and carcinogens from inhaled diesel particulates is not known; however, DNA adducts were found in the lungs of rats exposed to diesel exhaust particulates (IARC 1989, NTP 2000). Furthermore, more DNA adducts were found in lymphocytes from workers occupationally exposed to diesel exhaust than in those from workers exposed at lower or ambient levels (Hou et al. 1995, Nielsen et al. 1996). However, diesel exhaust exposure was not quantified in these studies, and exposure to used motor oil may have contributed to the adducts observed in one study.

\section{Properties}

Diesel exhaust is a complex mixture of combustion products of diesel fuel; the exact composition of the mixture depends on the nature of the engine, operating conditions, lubricating oil, additives, emission control system, and fuel composition (Obert 1973, Ullman 1989). Diesel engines typically are classified by their service requirements, and the operating conditions for light- and heavy-duty diesel engines differ with respect to engine speed, expected load, fuel composition, and engine emission controls. Light-duty vehicles, such as automobiles and light trucks, typically operate at higher speeds than do heavy-duty vehicles, such as trucks. Depending on operating conditions, fuel composition, and engine-control technology, lightand heavy-duty diesel engines, respectively, can emit 50 to 80 times and 100 to 200 times as much particulate mass as typical catalystequipped gasoline engines (McClellan 1986).

Most diesel exhaust particles have aerodynamic diameters falling within a range of 0.1 to $0.25 \mu \mathrm{m}$ (Groblicki 1979, Dolan et al. 1980, NRC 1982, Williams 1982). The particle size distribution of diesel exhaust is bimodal, with a nuclei mode of 0.0075 to $0.042 \mu \mathrm{m}$ (for particles formed by nucleation) and an accumulation mode of 0.042 to $1.0 \mu \mathrm{m}$ (for particles formed by agglomeration of nuclei particles) (Baumgard and Johnson 1996). Approximately 92\% of the particles emitted from diesel engines are less than $1.0 \mu \mathrm{m}$ in diameter (CARB 1997).

Diesel emissions consist of a nonpolar fraction (57\%), a moderately polar fraction (9\%), and a polar fraction (32\%) (Schuetzle and Perez 1983, Schuetzle et al. 1985); the remainder is unrecoverable. The inorganic fraction of the particulate emissions consists primarily of small elemental carbon particles, ranging from 0.01 to $0.08 \mu \mathrm{m}$ in diameter. Organic and elemental carbon account for approximately $80 \%$ of the total particulate matter mass. The remaining $20 \%$ is composed of sulfate (mainly sulfuric acid) (Pierson and Brachaczek 1983) 
and some inorganic additives and components of fuel and motor oil. In general, the organic compounds identified in diesel exhaust emissions contain hydrocarbons, such as alkanes and alkenes, hydrocarbon derivatives, aldehydes, PAHs, PAH derivatives, multifunctional derivatives of PAHs, heterocyclic compounds, heterocyclic derivatives, and multifunctional derivatives of heterocyclic compounds (Schuetzle 1988).

Because of their large surface area, diesel exhaust particulates can adsorb relatively large amounts of organic material coming from unburned fuel, lubricating oil, and pyrosynthesis during fuel combustion. A variety of mutagens and carcinogens, such as PAHs and nitro-PAHs, are adsorbed by the particulates (NRC 1982, Tokiwa and Ohnishi 1986, IPCS 1996). The organic-extractable fraction of diesel exhaust particulates is typically in the 20\% to 30\% range, but it may be as high as $90 \%$ (Williams et al. 1989), depending upon vehicle type and operating conditions. In general, incomplete combustion in diesel engines operating under low-load conditions produces relatively low particle concentrations and a higher proportion of organic material associated with the particles (Dutcher et al. 1984). Particulate matter produced at low exhaust-gas temperatures has more adsorbed soluble organics than does particulate matter produced at high exhaust-gas temperatures (Kishi et al. 1992).

\section{Use}

Diesel exhaust particulates have no known uses.

\section{Production}

Internal combustion engines have been used in cars, trucks, locomotives, and other motorized machinery for about 100 years (IARC 1989). Diesel exhaust has three major groups of sources: mobile sources (on-road vehicles and other mobile sources), stationary area sources (e.g., oil- and gas-production facilities, stationary engines, repair yards, and shipyards), and stationary point sources (e.g., chemical-manufacturing facilities and electric utilities). As discussed above, the composition and quantity of the emissions depend mainly on the type and condition of the engine, fuel composition and additives, operating conditions, and emission-control devices.

Diesel engines operate with excess air ( 25 to 30 parts air to 1 part fuel) (Lassiter and Milby 1978). The gas-phase fraction of emissions is composed primarily of typical combustion gases such as nitrogen, oxygen, carbon dioxide, and water vapor. As a result of incomplete combustion, the gaseous fraction also contains pollutants such as carbon monoxide, sulfur oxides, nitrogen oxides, volatile hydrocarbons, and low-molecular-weight PAHs and their derivatives. The total particulate emission concentration from light-duty diesel engines is much smaller than that from heavy-duty diesel engines. In general, newer heavy-duty trucks emit diesel particulates at a rate 20 times that of catalyst-equipped gasoline-fueled vehicles (IPCS 1996).

\section{Exposure}

Occupational exposure to diesel exhaust particulates has been studied among railroad workers, mine workers (who use diesel-powered equipment), bus-garage workers, trucking-company workers, forklift truck operators, firefighters, lumberjacks, toll-booth and parkinggarage attendants, and workers in many occupations involved in servicing or handling automobiles (e.g., car mechanics and professional drivers). The National Institute for Occupational Safety and Health estimated that 1.35 million workers were occupationally exposed to diesel exhaust particulates in 80,000 U.S. workplaces (MMWR 1989).

Railroad workers' potential for exposure has increased since 1959, when almost all of the U.S. railroad system (95\%) converted to diesel engines. In studies conducted between 1996 and 2002, occupational exposure to elemental carbon was reported to be 4 to $20 \mu \mathrm{g} / \mathrm{m}^{3}$ for train crews and 3 to $39 \mu \mathrm{g} / \mathrm{m}^{3}$ for maintenance crews (Pronk 2009). Exposure to respirable particulate matter ranged from $17 \mu \mathrm{g} / \mathrm{m}^{3}$ for clerks to $134 \mu \mathrm{g} / \mathrm{m}^{3}$ for locomotive shop workers (Woskie et al. 1988). More recently, the U.S. Environmental Protection Agency reported that exposure of locomotive workers to respirable particulate matter ranged from 39 to $191 \mu \mathrm{g} / \mathrm{m}^{3}$ (EPA 2002). In a railway repair facility in England, mean personal exposure to respirable particulate matter was $250 \mu \mathrm{g} / \mathrm{m}^{3}$, and the concentration in ambient air was $163 \mu \mathrm{g} /$ $\mathrm{m}^{3}$ (Groves and Cain 2000).

Diesel engines have been, and continue to be, commonly used in U.S. mines since their first introduction in the early 1950s. Exposure occurs from activities that use diesel-fueled heavy machinery, such as blasting. From 1997 to 2004, occupational exposure to respirable elemental carbon in U.S. underground mining operations ranged from 148 to $637 \mu \mathrm{g} / \mathrm{m}^{3}$ (Pronk et al. 2009). In surface mining operations, concentrations of respirable or submicron elemental carbon ranged from 13 to $23 \mu \mathrm{g} / \mathrm{m}^{3}$. In enclosed spaces of mines, diesel exhaust particulate concentrations were up to $1,280 \mu \mathrm{g} / \mathrm{m}^{3}$ (EPA 2002).

Exposure of mechanics in bus garages and truck terminals to respirable elemental carbon ranged from 20 to $40 \mu \mathrm{g} / \mathrm{m}^{3}$ (Pronk 2009). Levels of diesel exhaust emissions were elevated at a bus garage during peak hours of bus activity (i.e., starting of buses) but rapidly returned to normal in 10 to 15 minutes (Pryor 1983). In another study, mean personal exposure to respirable particulate matter was $267 \mu \mathrm{g} / \mathrm{m}^{3}$, and the mean concentration in ambient air was $211 \mu \mathrm{g} / \mathrm{m}^{3}$ (Groves and Cain 2000). At a New York City bus stop, respirable particulate matter from diesel exhaust was measured at $46.7 \mu \mathrm{g} / \mathrm{m}^{3}$ and was estimated to constitute $53 \%$ of the particulate matter in ambient air at that site (EPA 2002).

Exposure of truck drivers to elemental carbon in submicron particulate matter generally ranged from 1 to $10 \mu \mathrm{g} / \mathrm{m}^{3}$ (Pronk et al. 2009). Temperature was an important factor, with higher exposures occurring at higher temperatures (Zaebst et al. 1991). This study found no discernible difference between truckers' exposure levels $\left(3.8 \mu \mathrm{g} / \mathrm{m}^{3}\right)$ and highway background concentrations $\left(2.5 \mu \mathrm{g} / \mathrm{m}^{3}\right)$, indicating that the highway environment, rather than the truck itself, was the source of the truck drivers' exposure. Exposure of mechanics to elemental carbon in truck terminals ranged from 20 to $40 \mu \mathrm{g} / \mathrm{m}^{3}$.

Exposure of firefighters in fire stations to inhalable elemental carbon ranged from 10 to $40 \mu \mathrm{g} / \mathrm{m}^{3}$ (Pronk 2009). Diesel fire trucks idling in a fire station can spread exhaust throughout the entire station (NJDHSS 2001). Firefighters in New York, Boston, and Los Angeles were studied to determine exposure to diesel exhaust particulates (Froines et al. 1987). Total exposure to airborne particles was measured with personal air samplers, and sampling was performed only when firefighters were in the fire stations. For the three cities, total airborne particulate exposure had a time-weighted average ranging from below $100 \mu \mathrm{g} / \mathrm{m}^{3}$ to $480 \mu \mathrm{g} / \mathrm{m}^{3}$. For a "worst-case" scenario, the mean concentrations were as high as $748 \mu \mathrm{g} / \mathrm{m}^{3}$. The authors noted that these were busy fire stations in large metropolitan areas. Other factors, such as smoking, building design, age and maintenance of vehicles, activities of the firefighters, and timing of runs, also affected the results.

Occupational exposure to diesel exhaust from off-road vehicles was reported for construction and forklift operators in several settings (Pronk et al. 2009). Exposure to elemental carbon ranged from 132 to $314 \mu \mathrm{g} / \mathrm{m}^{3}$ for tunnel construction, compared with only 4 to $13 \mu \mathrm{g} / \mathrm{m}^{3}$ for outdoor highway construction. Exposure to inhalable or respirable elemental carbon was 4 to $122 \mu \mathrm{g} / \mathrm{m}^{3}$ for dockworkers, including forklift operators; 6 to $49 \mu \mathrm{g} / \mathrm{m}^{3}$ for workers loading and 
unloading ships; and $11 \mu \mathrm{g} / \mathrm{m}^{3}$ for airline personnel in baggage and screening. Three studies reviewed by the International Agency for Research on Cancer found that toll-booth workers had elevated levels of exposure to diesel exhaust particulates. In many of these studies, however, it was difficult to differentiate between gasoline exhaust and diesel exhaust (IARC 1989) .

\section{Regulations}

\section{Environmental Protection Agency (EPA)}

\section{Clean Air Act}

Mobile Source Air Toxics: Listed as a mobile source air toxic for which regulations are to be developed.

\section{Mine Safety and Health Administration (MSHA, Dept. of Labor)}

Standards have been developed for diesel exhaust monitoring and exposure mitigation in underground coal mines.

\section{Guidelines}

National Institute for Occupational Safety and Health (NIOSH, CDC, HHS) Listed as a potential occupational carcinogen.

\section{References}

Baumgard KJ, Johnson JH. 1996. The effect of Fuel and Engine Design on Diesel Exhaust Particle Size Distributions. SAE Technical Paper Series no. 960131. Warrendale, PA: Society of Automotive Engineers. Bhatia R, Lopipero P, Smith AH. 1998. Diesel exhaust exposure and lung cancer. Epidemiology 9(1): 84-91. Boffetta P, Silverman DT. 2001. A meta-analysis of bladder cancer and diesel exhaust exposure. Epidemiology 12(1): 125-130.

Boffetta P. 2004. Risk of acute myeloid leukemia after exposure to diesel exhaust: A review of the epidemiologic evidence. J Occup Environ Med 46(10): 1076-1083.

Brightwell J, Fouillet X, Cassano-Zoppi AL, Bernstein D, Crawley F, Duchosal F, Gatz R, Perczel S, Pfeifer H. 1989. Tumours of the respiratory tract in rats and hamsters following chronic inhalation of engine exhaust emissions. J Appl Toxicol 9(1): 23-31.

Brüske-Hohlfeld I, Möhner M, Pohlabeln H, Ahrens W, Bolm-Audorff U, Kreienbrock L, et al. 2000. Occupational lung cancer risk for men in Germany: Results from a pooled case-control study. Am J Epidemiol 151(4): 384-395.

CARB. 1997. Emission Inventory 1995. Sacramento, CA: California Air Resources Board.

Cohen AJ, Higgins MWP. 1995. Health effects of diesel exhaust: Epidemiology. In Diesel Exhaust. A Critical Analysis of Emissions, Exposure, and Health Effects. Cambridge, MA: Health Effects Institute. pp. 251-292. Dolan DF, Kittelson DB, Pui DYH. 1980. Diesel Exhaust Particle Size Distribution Measurement Techniques. SAE Technical Paper Series no. 870254. Warrendale, PA: Society of Automotive Engineers.

Dutcher JS, Sun JD, Lopez JA. 1984. Generation and characterization of radiolabeled diesel exhaust. Am Ind Hyg Assoc J 45(7): 491-498.

EPA. 2002. Health Assessment Document for Diesel Engine Exhaust. U.S. Environmental Protection Agency. http://www.epa.gov/ttn/atw/dieselfinal.pdf.

Froines JR, Hinds WC, Duffy RM. 1987. Exposure of firefighters to diesel emissions in fire stations. Am Ind Hyg Asso J 48(3): 202-207.

Garshick E, Laden F, Hart JE, Rosner B, Smith TJ, Dockery DW, Speizer FE. 2004. Lung cancer in railroad workers exposed to diesel exhaust. Environ Health Perspect 112(15): 1539-1543.

Garshick E, Laden F, Hart JE, Smith TJ, Rosner B. 2006. Smoking imputation and lung cancer in railroad workers exposed to diesel exhaust. Am J Ind Med 49(9): 709-718.

Garshick E, Laden F, Hart JE, Rosner B, Davis ME, Eisen EA, Smith TJ. 2008. Lung cancer and vehicle exhaust in trucking industry workers. Environ Health Perspect 116(10): 1327-1332.

Groblicki PJ. 1979. Particle Size Variation in Diesel Car Exhaust. SAE Technical Paper Series no. 790421. Warrendale, PA: Society of Automotive Engineers.

Groves J, Cain JR. 2000. A survey of exposure to diesel engine exhaust emissions in the workplace. Ann Occup Hyg 44(6): 435-447.

Gustavsson P, Jakobsson R, Nyberg F, Pershagen G, Järup L, Schéele P. 2000. Occupational exprosure and lung cancer risk: A population-based case-referent study in Sweden. Am J Epidemiol 152(1):32-40. Heinrich U, Fuhst R, Rittinghausen S, Creutzenberg O, Bellmann B, Koch W, Levsen K. 1995. Chronic inhalation exposure of Wistar rats and two different strains of mice to diesel-engine exhaust, carbonblack, and titanium-dioxide. Inhal Toxicol 7: 533-556.

Hou SM, Lambert B, Hemminki K. 1995. Relationship between hprt mutant frequency, aromatic DNA adducts and genotypes for GSTM1 and NAT2 in bus maintenance workers. Carcinogenesis 16(8): 1913-1917. IARC. 1989. Diesel and gasoline engine exhausts. In Diesel and Gasoline Engine Exhausts and Some Nitroarenes. IARC Monographs on the Evaluation of Carcinogenic Risk of Chemicals to Humans, vol. 46. Lyon, France: International Agency for Research on Cancer. pp. 41-185.

IPCS. 1996. Environmental Health Criteria No. 171. Diesel Fuel and Exhaust Emissions. International Programme on Chemical Safety. http://www.inchem.org/documents/ehc/ehc/ehc171.htm.
Järvholm B, Silverman D. 2003. Lung cancer in heavy equipment operators and truck drivers with diesel exhaust exposure in the construction industry. Occup Environ Med 60(7): 516-520.

Kauppinen T, Heikkilä P, Partanen T, Virtanen SV, Pukkala E, Ylöstalo P, Burstyn I, Ferro G, Boffetta P. 2003. Mortality and cancer incidence of workers in Finnish road paving companies. Am J Ind Med 43(1): 49-57. Kishi Y, Tohno H, Ara M. 1992. Characteristics and Combustability of Particulate Matter. Reducing Emissions from Diesel Combustion, Warrendale, PA: Society of Automotive Engineers. pp. 139-146.

Laden F, Hart JE, Eschenroeder A, Smith TJ, Garshick E. 2006. Historical estimation of diesel exhaust exposure in a cohort study of U.S. railroad workers and lung cancer. Cancer Causes Control 17(7): 911-919. Larkin EK, Smith TJ, Stayner L, Rosner B, Speizer FE, Garshick E. 2000. Diesel exhaust exposure and lung cancer: Adjustment for the effect of smoking in a retrospective cohort study. Am JInd Med 38(4): 399-409. Lassiter DV, Milby TH. 1978. Health Effects of Diesel Exhaust Emission: A Comprehensive Literature Review, Evaluation and Research Gaps Analysis. U.S. NTIS PB-282-795. Washington, DC:American Mining Congress. Lipsett M, Campleman S. 1999. Occupational exposure to diesel exhaust and lung cancer: A meta-analysis. Am J Public Health 89(7): 1009-1017.

McClellan RO. 1986. Toxicological effects of emissions from diesel engines. Dev Toxicol Environ Sci 13: 3-8. MMWR. 1989. Publication of NIOSH Current Intelligence Bulletin on carcinogenic effects of diesel exhaust. Morbid Mortal Wkly Rep 38(5): 76-78.

Neumeyer-Gromen A, Razum 0, Kersten N, Seidler A, Zeeb H. 2009. Diesel motor emissions and lung cancer mortality —results of the second follow-up of a cohort study in potash miners. Int J Cancer 124(8): 1900-1906.

Nielsen PS, Andreassen A, Farmer PB, Ourebø S, Autrup H. 1996. Biomonitoring of diesel exhaust-exposed workers. DNA and hemoglobin adducts and urinary 1-hydroxypyrene as markers of exposure. Toxicol Lett 86(1): 27-37.

Nikula KJ, Snipes MB, Barr EB, Griffith WC, Henderson RF, Mauderly JL. 1995. Comparative pulmonary toxicities and carcinogenicities of chronically inhaled diesel exhaust and carbon black in F344 rats. Fundam Appl Toxicol 25(1): 80-94.

NJDHSS. 2001. Diesel Exhaust in Fire Stations. New Jersey Department of Health and Senior Services. http:// www.state.nj.us/health/eoh/peoshweb/dieselib.pdf.

NRC. 1982. Diesel Cars: Benefits, Risks, and Public Policy: Final Report of the Diesel Impacts Study Committee, Assembly of Engineering, National Research Council. Washington, DC: National Academy Press. 142 pp.

NTP. 2000. Report on Carcinogens Background Document for Diesel Exhaust Particulates. Research Triangle Park, NC: National Toxicology Program. 196 pp.

Obert EF. 1973. Internal Combustion Engines and Air Pollution, 3rd ed. New York: Harper and Row.

Parent ME, Rousseau MC, Boffetta P, Cohen A, Siemiatycki J. 2007. Exposure to diesel and gasoline engine emissions and the risk of lung cancer. Am J Epidemiol 165(1): 53-62.

Pierson WR, Brachaczek WW. 1983. Particulate matter associated with vehicles on the road II. Aerosol. Sci Tech 2: 1-40.

Pronk A, Coble J, Stewart PA. 2009. Occupational exposure to diesel engine exhaust: A literature review. J Expo Sci Environ Epidemiol 19(5): 443-457.

Pryor P. 1983. Health Hazard Evaluation. Trailways Bus System, Denver, CO. Report no. HETA 81-416-1334. Cincinnati, $\mathrm{OH}$ : National Institute for Occupational Safety and Health. $11 \mathrm{pp}$.

Schuetzle D, Perez JM. 1983. Factors influencing the emissions of nitrated-polynuclear aromatic hydrocarbons (nitro-PAH) from diesel engines. J Air Pollut Control Assoc 33(8): 751-755.

Schuetzle D, Jensen TE, Ball JC. 1985. Polar polynuclear aromatic hydrocarbon derivatives in extracts of particulates: Biological characterization and techniques for chemical analysis. Environ Int 11(2-4): 169-181. Schuetzle D. 1988. Organic tracers for source apportionment of combustion emissions to ambient air particulates [Abstract]. Presented at the Sixth Symposium on Environmental Analytical Chemistry: Chemistry and Source Apportionment in Ambient and Indoor Atmospheres, 6/27-29/88, Provo, UT.

Tokiwa H, Ohnishi Y. 1986. Mutagenicity and carcinogenicity of nitroarenes and their sources in the environment. Crit Rev Toxicol 17(1): 23-60.

UIIman TL. 1989. Investigation of the Effects of Fuel Composition on Heavy Duty Diesel Engine Emissions. SAE Technical Paper No. 892072. Society of Automotive Engineers.

Williams DJ, Milne JW, Roberts DBK, M.C. 1989. Particulate emission from "in use" motor vehicles-II. Diesel vehicles. Atmos Environ 23: 2647-2661.

Williams RL. 1982. Diesel particulate emissions: Composition, concentration, and control. Dev Toxicol Environ Sci 10: 15-32.

Woskie SR, Smith TJ, Hammond SK, Schenker MB, Garshick E, Speizer FE. 1988. Estimation of the diesel exhaust exposures of railroad workers: II. National and historical exposures. Am J Ind Med 13(3): 395-404. Zaebst DD, Clapp DE, Blade LM, Marlow DA, Steenland K, Hornung RW, Scheutzle D, Butler J. 1991. Quantitative determination of trucking industry workers' exposures to diesel exhaust particles. Am Ind Hyg Assoc J 52(12): 529-541. 